\title{
Viability of 'Dilute and Attenuate' Landfill as a Final Disposal Method for Solid Waste in Nigeria
}

\author{
Rabia Lawal Batagarawa ${ }^{1^{*}} \quad$ John Williams ${ }^{2}$ \\ 1.Civil Engineering Department, Nigerian Defence Academy, PO box 2109, Kaduna, Nigeria \\ 2.School of Civil Engineering and Surveying, University of Portsmouth, Portland Building, PO1 3AH, UK
}

\begin{abstract}
The predominant disposal method of solid waste management in the world is landfilling while that of Nigeria remains open dumping and open burning. The aim of this study is to evaluate the viability of 'Dilute and Attenuate' landfill as a final disposal method for solid waste in Nigeria. A 'dilute and attenuate' landfill was evaluated by assessing groundwater and landfill gas. Water samples for laboratory tests were collected upstream and downstream of the landfill site. Laboratory tests are $\mathrm{pH}$, Conductivity, biochemical oxygen demand (BOD), chemical oxygen demand (COD), suspended solids (SS), volatile suspended solids, ammonia and heavy metals. The landfill gas was assessed onsite from seven (7) gas sampling points across the landfill site using an infrared gas analyser. The presence of methane and carbon dioxide at all the gas sampling points except Cell D shows that the landfill has not reached full stabilization and therefore, has a mild potential to contaminate the surrounding. There is no significant difference between the values of $\mathrm{pH}$, conductivity, COD, BOD and Ammonia of groundwater in the wells upstream and downstream of the landfill site the values generally within acceptable limits for potable water.
\end{abstract}

Keywords: 'Dilute and Attenuate' Landfill, Nigeria, final disposal, solid waste, contained landfill

DOI: $10.7176 / \mathrm{CER} / 11-10-07$

Publication date: November $30^{\text {th }} 2019$

\section{Introduction}

There is a general lack of human resources with technical expertise necessary for solid waste management planning and operation as well as inappropriate selection of waste management techniques in most developing countries such as Nigeria (Barton et al. 2008; Adewole, 2009). This is in addition to a steady increase in waste quantity and variety due to population growth and industrialization in Nigeria, while the basic solid waste management system based on collection, transportation and disposal remains highly inefficient and ineffective, especially in the urban centres (Ayotamuno and Gobo, 2004; Imam et al., 2007). The estimated per capita waste generated is $0.49 \mathrm{~kg}$ in the country with a population of over a 150 million across a landmass of $923,800 \mathrm{~km}^{2}$ (Ogwueleka, 2009; WDI, 2010). The disposal options employed are open dumping, open burning and composting; and an estimated recycling rate of 8-22\% (Dauda and Osita, 2003; Ogwueleka, 2009; Wilson et al., 2009)

\subsection{Landfills}

The predominant disposal method of solid waste management in the world is landfilling despite its low position on the disposal hierarchy compared to composting, incineration, recycling and anaerobic digestion and accounts for over $50 \%$ of municipal solid waste disposal in high, medium and low income countries with the exception of a few European countries

(Hoornweg et al., 2012). Generally, it is the cheapest, simplest and most practical waste disposal method considering economic, technical and regulatory aspects (Bialowiec, 2011). In addition, wastes treated by other methods generally have residuals that end up in the landfills. It is therefore an integral part of solid waste management, which aims at ensuring the protection of health and environment while conserving resources (Brunner and Fellner, 2007). Although developed countries have achieved the first aim, developing countries such as Nigeria are still battling with the protection of health and environment from inadequate solid waste management systems (Ibid). However, many affluent developed countries such as Germany, Netherland and Austria with their high level of technological expertise and educational level are moving towards $0 \%$ landfilling (EU, 2009)

An effective strategy is required to ensure the objectives of solid waste management, which include collection, transportation, sorting, treatment and final disposal, are met. Solid wastes are accumulated from human and animal activities and include household, commercial, industrial and agricultural wastes with a high percentage of biodegradable waste from households. A rising concern for the disposal of solid wastes stems from the growth in waste quantity, escalating costs of disposal, and changing composition of waste with greater quantities of toxic materials as a result of rising levels of affluence, cheaper consumable products, proliferation of packaging, the advent of built in obsolescence, demand for convenience goods and change in consumption pattern (Tcholanoglous, Theisen and Vigil, 1993; Imam et al., 2007)

Landfills are engineered facilities designed and operated for land disposal of solid or hazardous wastes in a manner that protects the environment (Mihelcic and Zimmerman 2010; Worrell and Vesilind 2012). It is generally 
a large hole in the ground or above ground where wastes are placed and compacted, then covered to limit exposure into the environment (Misgav et al., 2000; Mihelcic and Zimmerman 2010).

Solid wastes are characterized by physical, chemical and biological processes. The biological processes are mainly responsible for the drawbacks associated with landfilling - its potential for environmental pollution and public hazard problems due to leachate and landfill gas. Landfill gas is made up of mainly methane and carbon dioxide, two significant green house gases. Leachates are highly toxic liquids with great contamination capacity when they come in contact with ground water (Fatta et al., 2001; Worrel \& Vesilind, 2012). The biodegradable matter in the landfill undergoes aerobic and anaerobic forms of decomposition. The chemical and biological reactions determine the quantity and composition of gas and leachate produced by the landfill and the management required (Mihelcic \& Zimmerman, 2012).

Aerobic decomposition begins after waste is deposited and continues until entrapped oxygen is used up or is insufficient to support the process. This process mainly generates water, carbon dioxide, ammonia and sulfates with slight odour problems arising from organic esthers (Tcholanoglous et al., 1993; Mihelcic and Zimmerman 2010; Worrell and Vesilind 2012). The anaerobic decomposition takes place in many stages with each stage having an impact on the gas and leachate production before stabilization. First, wastes are hydrolyzed and fermented by microbes to breakdown complex organic molecules with the production of hydrogen and carbon dioxide. Next, methanogenic bacteria break down fatty acids and alcohols into methane and carbon dioxide or methane and water in the presence on hydrogen. The stages of waste degradation occur concurrently in most landfill environments with methane to carbon dioxide ratio of 3:2. Figure 1 shows gas production phases in a typical landfill.

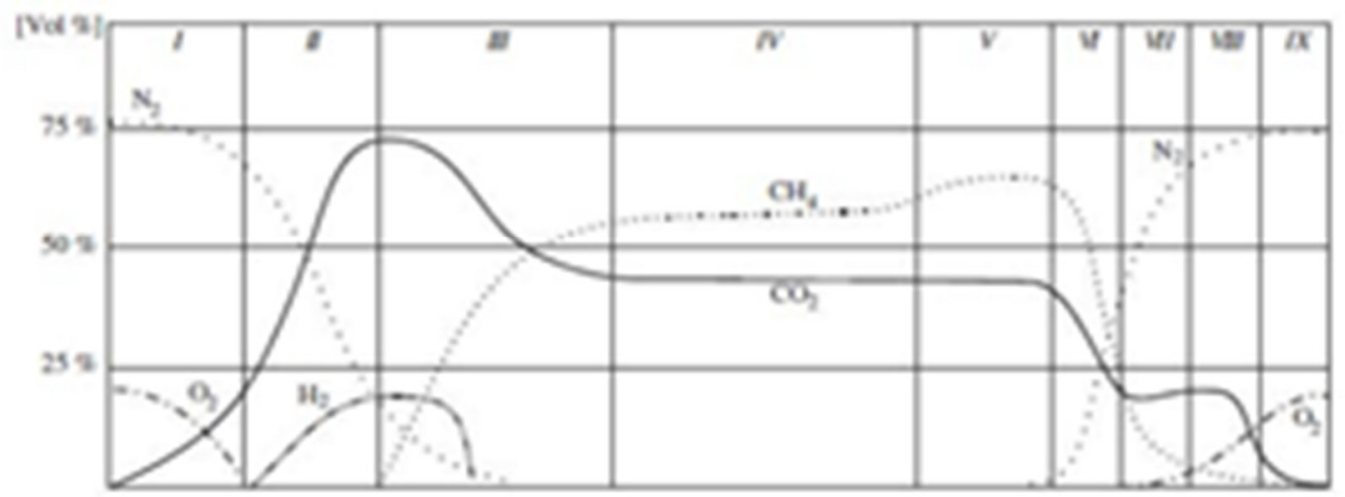

Figure 1 Landfill gas production phases (Mihelcic \& Zimmerman, 2010)

The stabilization of waste proceeds is in five distinct stages with the rate and characteristics of leachate and gas produced reflecting the microbial processes in the landfill (Worrel and Vesilind 2012).

Phase 1: Initial adjustment phase

Initial placement of solid waste and accumulation of moisture to support microbial activity in the landfill occurs in this phase. This creates favorable conditions for biochemical decomposition (Worrel and Vesilind, 2012)

Phase II: Transition stage

The placement is generally completed at this stage and the environment to anaerobic. Presence of nitrates and sulfates is detected and oxygen is replaced by carbon dioxide. Measurable concentrations of chemical oxygen demand can be detected in the leachate at the end of this phase.

Phase III: Acid formation

Production of high concentrations of intermediate volatile organic acids is recorded in this phase from continuous hydrolysis of solid waste and a decrease in $\mathrm{pH}$.

Phase IV: Methane fermentation phase

Intermediate acids are consumed by methanogenic bacteria and converted into methane and carbon dioxide. Nitrates and sulfates are converted into ammonia and sulfides.

Phase v: Maturation

Biological activity begins to wane as nutrients and substrates become limited. Leachate strength becomes steady at low concentrations while gas productions drops significantly while oxygen and oxidized species begin to be detected.

\subsection{Types of Landfills}

Landfills can be categorized into 'dilute and attenuate', 'bioreactor' and contained landfills. In the case of 'Dilute and attenuate' landfill, the principle of leachate and gas management relies on attenuation mechanisms operating within the body of the waste and the natural low permeability and attenuation characteristics of geological barriers. 
This method allows seepage of leachate, though mitigated and diluted, into the environment. The unchannelled landfill gas is also allowed to escape into the atmosphere and had caused serious odours and fire blow-ups in the past (Allen, 2001).

These 'Contained' landfill sites are intended to ensure complete containment of landfill emissions with the emissions taken out in controlled systems for environmental safety. These sites require a larger degree of site design, engineering and management and exercise a greater degree of control over risks associated with landfilling of waste. This is achieved by using clays with very low permeability and/or installation of single or multi barrier clay-membrane systems at the base, sides and top of landfill cells. The composite multi-barrier clay membrane systems consist of sheets of synthetic materials interlaid with clay mineral material; leak detection, leachate collection and gas collection systems installed into the lining and beneath the capping material (Allen, 2000). This type of landfill takes a high number of years to attain stabilization.

To significantly reduce the number of years to attain stabilization, the bioreactor landfills have been developed to maximize infiltration of water into the waste under controlled conditions with the aim of maximizing gas generation rates while reducing the movement of leachate. It is more expensive to develop e compared to contained landfill (Warith, 2001). However, the sale of gas overcomes the expense.

\section{3 water quality}

Because of the potential of all types of landfills to pollute, surrounding environments of sites are commonly monitored by operators to determine the effect of the site(s). The soil, groundwater and air are generally evaluated at specific intervals based on regulations of specific locations. The World Health Organization (WHO) has formed international standards for potable water that serves as a basis for regulation in both developed and developing countries to ensure the protection of public health. Nigeria has a drinking water quality standard based on WHO. The maximum permitted or allowable limits of elements are set to ensure effective health protection and are shown in Table 1.

Table 1. Water quality standards

\begin{tabular}{|l|l|l|}
\hline Parameter & Limits - Nigeria based on WHO) & Limits - EU/DWI \\
\hline $\mathrm{pH}$ & $6.5-8.5$ & \\
\hline Conductivity $\mu \mathrm{S} / \mathrm{cm}$ & 1000 & \\
\hline Iron $\mathrm{mg} / \mathrm{l}$ & $0.3 \mathrm{mg} / \mathrm{l}$ & $0.3 \mathrm{mg} / 1$ \\
\hline Lead mg/l & $0.01 \mathrm{mg} / \mathrm{l}$ & $0.01 \mathrm{mg} / \mathrm{l}$ \\
\hline Cadmium mg/l & $0.003 \mathrm{mg} / \mathrm{l}$ & $0.005 \mathrm{mg} / \mathrm{l}$ \\
\hline Nickel mg/l & $0.02 \mathrm{mg} / 1$ & $0.02 \mathrm{mg} / 1$ \\
\hline COD & - & - \\
\hline BOD & - & - \\
\hline Ammonia & - & - \\
\hline
\end{tabular}

(WHO, 2008; DWI)

\subsection{Post closure and sustainability}

Generally, a landfill operator is responsible for post-closure monitoring and maintenance of landfills until the facility has ceased causing and is unlikely to cause future environmental pollution while revenue income has stopped with no input of waste. This is in addition to liabilities due to failure (leachate or gas migration and environmental pollution) before waste stabilization. This long-term liability is a long-term threat to the landfill operator, the regulatory bodies and the general public (Mather, 1995; Allen 2001;). The post-closure care includes the land re-use plan of the site.

The significant time delay of attaining stabilization of the total containment of landfilled solid waste leaves a burden for the future generations of dealing with past waste as well as theirs. This is contrary to one of the principle of sustainable development, which indicates that humans bear the responsibility to protect and improve the environment for present and future generations (UN, 1972 in Mihelcic \& Zimmerman, 2010).

In view of environmental sustainability; prolonged stability of contained landfills, its high cost and the need for high skilled labour renders it prudent to re-evaluate the adoption of dilute and attenuate landfills despite their being obsolete in developed countries particularly in Europe. This research aims at assessing the 'dilute and attenuate' landfills in comparison to the 'contained' landfill as a viable means of disposing solid waste in Nigeria.

\section{Methodology}

A 'dilute and attenuate' landfill was identified in the UK to evaluate the effect of landfill on the environment by assessing groundwater and landfill gas. Information about the landfill was obtained by evaluating ground water around the site over a period of four weeks. Water samples for laboratory tests were collected for the evaluation. Additional information was obtained using structured questionnaires from the staff of Hampshire county council. The landfill gas was assessed onsite for the four weeks from seven (7) gas sampling points across the landfill site. 


\subsection{Site locations}

The 'dilute and attenuate' site identified (Buriton landfill site) was operated for 20 years and had been closed for 10 years at the time of study. It was managed by the Hampshire county council and took in mostly domestic waste during its operational years.

\section{2 site analysis}

At the Buriton site, ground water was collected at 2 out of 4 existing sample points for laboratory experiments. The sample points are upstream and downstream of the landfill to identify its effect on the surrounding groundwater. Landfill gas was evaluated onsite at 7 sample points using an infrared gas analyzer to establish gas quality (levels of methane, carbon dioxide and oxygen). The sample collection points are shown in figures 2 and 3 . A leachate well collector was used to collect water from wells of 40-50m depth.

\subsection{Laboratory analysis}

Laboratory tests conducted on groundwater samples from both wells include $\mathrm{pH}$, Conductivity, biochemical oxygen demand (BOD), chemical oxygen demand (COD), suspended solids (SS), volatile suspended solids, ammonia and heavy metals.

$\mathrm{PH}$

$\mathrm{PH}$ is the measure of Acid-Base chemistry with a scale of 0-14 in aqueous systems where acidic solutions have a pH below 7 and basic solutions above 7 (Mihelcic \& Zimmerman, 2010). The acid-base chemistry is important in the treatment of pollution and understanding the toxicity of chemicals discharged into the environment. A pH meter (GENWAY 3305) was used to establish $\mathrm{pH}$ by inserting an attached probe into the leachate and groundwater samples. The results were read off the $\mathrm{pH}$ meter screen.

Conductivity, Ec

Conductivity is a measure of the ability of water to pass an electrical current. Conductivity in water is affected by the presence of inorganic dissolved solids such as chloride and nitrates (EPA, 2012) The conductivity of each sample was determined by inserting a probe attached to the conductivity meter (JENWAY) directly into the sample for reading.

Chemical oxygen demand, COD

COD tests are applied to evaluate poorly biodegradable or toxic waste (Mihelcic \& Zimmerman, 2010). This is the amount of chemical oxidant required to completely oxidize a source of organic matter. $2 \mathrm{mls}$ of the ground water was added to COD digesting tubes containing a solution of $86 \%$ sulfuric acid, mercury sulfate and chromium trioxide. The solution is heated to a temperature of $150^{\circ} \mathrm{C}$ to reflux the mixture and the COD read off the calorimeter screen.

Biochemical oxygen demand, BOD5

The BOD is a fundamental tool in the assessment of waste treatment and water quality with the objective determining the amount of microorganisms in water (Mihelcic \& Zimmerman, 2010). BOD is the amount of oxygen utilized by microorganisms in oxidizing carbonaceous nitrogenous organic matter. The laboratory analysis of $\mathrm{BOD}_{5}$ is the BOD exerted over an incubation period of 5 days. The BOD values were determined using a 50B YSI dissolved oxygen meter by inserting an attached probe into the prepared sample on the day of collection and after 5 days to obtain two DO readings $\mathrm{S}_{1}$ and $\mathrm{S}_{2}$ respectively. 1-day and 5-day dissolved oxygen of distilled water is also determined to be used in the BOD analysis $\left(\mathrm{B}_{1}\right.$ and $\left.\mathrm{B}_{2}\right)$ using equation 1 .

$$
\frac{1}{F}\left[\left(\mathrm{~S}_{1}-\mathrm{S}_{2}\right)-\left(\mathrm{B}_{1}-\mathrm{B}_{2}\right)\right]
$$

Suspended Solids, SS

Suspended solids (SS) and volatile suspended solids (VSS) are used as a measure of the number of microorganisms in the water or waste water (Mihelcic \& Zimmer, 2010). Specific volumes of groundwater samples were filtered using a Buchner funnel and micro fibre filter papers. Water was suctioned into a suction jar with that uses an air compressor and the filtrate collected on the filter paper. The filtrate is dried in an oven at $105^{\circ} \mathrm{C}$ for 2 hours and weighed. Suspended Solids is determined by:

$\mathrm{SS}=$

$\mathrm{D}=$ weight of filtrate after drying and subtracting weight of filter paper

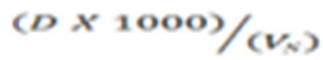

$\mathrm{V}_{\mathrm{S}}=$ volume of sample

Volatile Suspended Solids, VSS

The filtrate is further heated at $500^{\circ} \mathrm{C}$ for the volatile content of the solids to disintegrate. This weighed to determine the Volatile suspended solids thus: 
$\mathrm{VSS}=\{[(A-C)-(B-C)] \times 1000\} / V_{S}$

$\mathrm{A}=$ weight of filtrate after drying at $105^{\circ} \mathrm{C}$

$\mathrm{B}=$ weight of filtrate after burning at $500^{\circ} \mathrm{C}$

$\mathrm{C}=$ weight of filtrate paper

Ammonia $\mathrm{NH}_{4}$

The palintest photometer 5000 was used in determining the ammonia at a wavelength of $640 \mathrm{~nm}$. The samples are measured by inserting the reagent tablets into the sample in a test tube and the LCD reading is recorded.

Heavy metals

$2 \mathrm{mls}$ nitric acid was added to each sample to attain a $\mathrm{pH}$ of 2 to dissociate ions into the solution to be detected. An SP9 atomic absorption spectrophotometer was used to determine each of the four metals identified with different lamp settings and wavelengths. A thin suction tube is inserted into the samples for about a minute to determine the metals.

\section{Results and Discussion}

The results of gas quality and groundwater characteristics obtained from field and laboratory tests carried out across four (4) weeks for two groundwater and seven gas sample points are shown and discussed below.

\subsection{Landfill gas}

The presence of methane and carbon dioxide at all monitoring stations except Cell D shows that the landfill has not reached stabilization and therefore, has the potential to contaminate the surrounding (Worrel and Vesilind 2012). Less than $30 \%$ methane gas and a corresponding carbon dioxide generation of similar levels recorded in all the cells indicate the last stages of microbial processes in landfills before stabilization. Cell $\mathrm{D}$ has the highest potential to contaminate the environment with methane and gas carbon dioxide levels of $28 \%$ and $20 \%$ respectively at stage VI while the most stable cell is $\mathrm{C}$ with an insignificant methane level at stage IX. However, both gases are within the maturation stage and at a decline at all seven sampling points (Cells A to G) (Worrel and Vasilind, 2012).

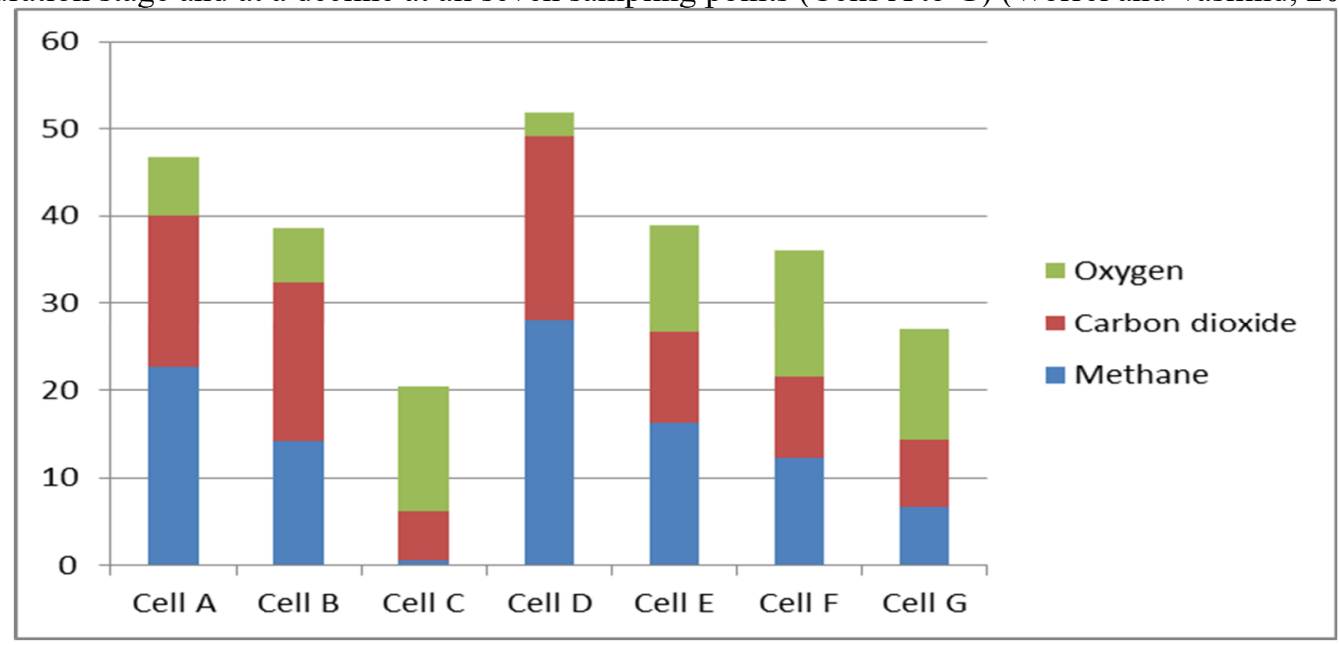

Fig 2. Landfill gas quality

3.2 Ground water quality upstream and downstream of the landfill site

The results of groundwater evaluation before (well A) and after (well B) the dilute and attenuate landfill site is shown in Table 2.

3.2.1 PH, Conductivity, Chemical Oxygen Demand (COD), Biological Oxygen Demand (BOD) \& Ammonia There is no significant difference between the values of $\mathrm{pH}$, conductivity, COD, BOD and Ammonia of groundwater in wells A and D. The $\mathrm{pH}$ values both upstream and downstream are within acceptable limits for potable water.

3.2.2 Heavy metals

The values of lead and cadmium from Wells A \& B are within the same range but both are above the limits set by WHO. Iron and nickel have an appreciable difference in quantities found in the two wells that are both above the acceptable limits. 
Table 2. Ground water quality of the dilute and attenuate landfill site

\begin{tabular}{|c|c|c|c|}
\hline Variable & Well A & Well B & $\begin{array}{l}\text { Limits } \\
\text { (WHO/Nigeria) }\end{array}$ \\
\hline $\mathrm{pH}$ & 7.5 & 7.4 & $6.5-8.5$ \\
\hline Conductivity Ec $\left(\mathrm{m}_{\mathrm{s}}\right)$ & 0.5 & 0.4 & - \\
\hline $\mathrm{COD}(\mathrm{mg} / \mathrm{l})$ & 10 & 10 & - \\
\hline $\mathrm{BOD}(\mathrm{mg} / \mathrm{l})$ & 1.5 & 1 & - \\
\hline $\mathrm{NH}_{4}(\mathrm{mg} / \mathrm{l})$ & 0.1 & 0.1 & - \\
\hline Lead (mg/l) & 0.17 & 0.22 & 0.01 \\
\hline Iron $(\mathrm{mg} / \mathrm{l})$ & 2.4 & 5 & 0.3 \\
\hline Cadmium (mg/l) & 0.02 & 0.03 & 0.003 \\
\hline Nickel (mg/l) & 0.07 & 0.21 & 0.02 \\
\hline
\end{tabular}

\section{Conclusion}

Stabilization has almost been attained from the levels of methane recorded in each cell across the dilute and attenuate landfill site ten years after closure. Although microbial activity is still present from the gas quality within most of the cells and therefore the potential to contaminate the surrounding still exists, the ground water quality evaluated shows no effect of the landfill contamination as there is no appreciable difference in the parameters of the groundwater in the wells before and after the landfill. This study shows the potential of the 'dilute and attenuate' landfill as a viable option for waste disposal in Nigeria to replace open dumping and open burning.

\section{References}

Adewole, A. (2009). Waste management towards sustainable development in Nigeria: A case study of Lagos state. International NGO Journal, 4(4), 173-179.

Barton, J., Issaias, I., \& Stentiford, E. (2008). Carbon-Making the right choice for waste management in developing countries. Waste Management, 28(4), 690-698.

Bialowiec, A. (2011). Hazardous Emissions from Municipal Solid Waste Landfills. In Contemporary Problems of Management and Environmental Protection "Some Aspects of Environmental Impact of Waste Dumps" (pp. 7-28).

Brunner, P., \& Fellner, J. (2007). Setting priorities for waste management strategies in developing countries. Waste Management \& Research, 25(3), 234.

Dauda, M., \& Osita, O. (2003). Solid waste management and re-use in Maiduguri, Nigeria. Paper presented at the 29th WEDC International Conference: Towards the millennium goals, Abuja, Nigeria.

Department for Environment, Food \& Rural Affairs. (2014). UK Statistics on Waste. Government Statistical Service. $\quad$ Retrieved $\quad 5^{\text {th }} \quad$ march $\quad 2015$ from https://www.gov.uk/government/uploads/system/uploads/attachment_data/file/363004/UK_Statistical_relea se_FINALv4_10_10_2014.pdf

Drinking Water Inspectorate (DWI); http://www.dwi.gov.uk

EPA (2012). Conductivity. Water: monitoring and assessment. United States Environmental Protection Agency

Hoornweg, D. \& Bhada-Tata, P. (2012). What a Waste : A Global Review of Solid Waste Management. World Bank. https://openknowledge.worldbank.org/handle/10986/17388 License: CC BY 3.0 IGO.”

Imam, A., Mohammed, B., Wilson, D., \& Cheeseman, C. (2008). Solid waste management in Abuja, Nigeria. Waste Management, 28(2), 468-472.

Mather, J.D. (1995). Preventing groundwater pollution from landfilled waste - is engineered containment an acceptable solution?

Mihelcic, J. R. \& Zimmerman, J. B. (2010). Environmental Engineering: Fundamentals, Sustainability, Design. New Jersey: John Wiley \& Sons.

Ogwueleka, T. (2009). Municipal Solid Waste Characteristics And Management In Nigeria. Iranian Journal of Environmental Health Science \& Engineering, 6(3).

Tchobanoglous, G., Theisen, H., Vigil, S., 1993. Integrated Solid Waste Management, Engineering Principles and Management Issues. McGraw Hill, New York, USA

Warith, M. (2001). Bioreactor landfills: Experimental and field results. Waste Management, 22, 7-17

WHO (2008). Guidelines for drinking-water quality, 3rd edition incorporating 1st and 2nd addenda. Vol. 1. Recommendations. Geneva, World Health Organization http://www.who.int/water_sanitation_health/dwq/GDW12rev1and2.pdf

Wilson, D., Araba, A., Chinwah, K., \& Cheeseman, C. (2009). Building recycling rates through the informal sector. Waste Management, 29(2), 629-635. 
Rabia L Batagarawa is currently a Senior Lecturer in the Nigerian Defence Academy in the field of Environmental Engineering with particular interests in solid waste management. This author became a Member of the Council for the Regulation of Engineering in Nigeria (COREN) in 2018 and an Affiliate Member of the Chartered Institution of Wastes Management, UK in 2015. RL Batagarawa was born in Nigerian on the 29th of September 1979. She has a PhD \& MSc in Civil Engineering from the University of Portsmouth in the UK (in 2011 and 2004 respectively); and a BEng from Abubakar Tafawa Balewa University, Buuchi, Nigeria in 2002

John B Williams is a Professor of Environmental Technology at the School of Civil Engineering and Surveying, University of Portsmouth, UK. He is the research coordinator for the department and is a Member of the Chartered Institution of Water and Environmental Management. He is a chartered Environmentalist and a fellow of the Higher Education Academy. He has a BSc in Resources Science from Kingston University, UK and a PhD on constructed wetlands at Portsmouth Polytechnic, UK in 1988. 